\title{
Akkreditáció az egészségügyben
}

\author{
Fügedi Gergely dr. - Lám Judit dr. - Belicza Éva dr.
}

Semmelweis Egyetem, Egészségügyi Közszolgálati Kar, Egészségügyi Menedzserképző Központ, Budapest

\begin{abstract}
Az egészségügy és a gyógyítóeljárások rohamléptékű fejlődése mellett a XXI. században egyre inkább középpontba kerül az ellátás hatékonysága, az intézményi múködés és a biztonságos betegellátás kérdésköre. A betegbiztonság növelésének tudományosan is bizonyítottan eredményes eszköze az akkreditáció, amely bár lassan több mint száz éve jelen levő eszköz az egészségügyben, robbanásszerű terjedése csak az 1990-es évektől indult meg. A közeli jövőben Magyarországon is elinduló, hazai fejlesztésű akkreditációs rendszer múködtetésében és sikerében meghatározó tényező lesz az egészségügy szereplőinek támogatása és aktív részvétele - ez azonban nem várható el az alapvető célok és jellemzók ismerete nélkül. Bonyolítja az új rendszerben való eligazodást és ahhoz való viszonyulást a magyar ellátók által már jól ismert ISO tanúsítás jelenléte. Jelen összefoglaló rövid áttekintést kíván nyújtani az egészségügyi akkreditáció fejlődéséről, céljairól, múködéséről és jelentőségéről, valamint a tanúsítással való hasonlóságokról és eltérésekről. Orv. Hetil., 2016, 157(4), 138-145.
\end{abstract}

Kulcsszavak: minőségügy, akkreditáció, betegbiztonság, minőségfejlesztés

\section{Accreditation in health care}

Besides the rapid development of healing procedures and healthcare, efficiency of care, institutional performance and safe treatment are receiving more and more attention in the 21 st century. Accreditation, a scientifically proven tool for improving patient safety, has been used effectively in healthcare for nearly a hundred years, but only started to spread worldwide since the 1990s. The support and active participation of medical staff are determining factors in operating and getting accross the nationally developed, upcoming Hungarian accreditation system. However, this active assistance cannot be expected without the participants' understanding of the basic goals and features of the system. The presence of the ISO certification in Hungary, well-known by healthcare professionals, further complicates the understanding and orientation among quality management and improvement systems. This paper aims to provide an overview of the history, goals, function and importance of healthcare accreditation, and its similarities and differences regarding ISO certification.

Keywords: quality management, accreditation, patient safety, quality improvement

Fügedi, G., Lám, J., Belicza, É. [Accreditation in health care]. Orv. Hetil., 2016, 157(4), 138-145.

(Beérkezett: 2015. október 8.; elfogadva: 2015. október 29.)

\begin{abstract}
Rövidítések
ACS = (American College of Surgeons) Amerikai Sebésztársaság; ALPHA = Agenda for Leadership in Programs for Healthcare Accreditation; BELLA = BetegELLátók Akkreditációja a biztonságos betegellátásért; $\mathrm{DUQuE}=$ Deepening our understanding of quality improvement in Europe; ISO = (International Organization for Standardization) Nemzetközi Szabványügyi Szervezet; ISQua = International Society for Quality in Health Care; JCAH = Joint Commission on Accreditation of Hospitals; JCI = Joint Commission International; TÁMOP = Társadalmi Megújulás Operatív Program; WHO = (World Health Organization) Egészségügyi Világszervezet
\end{abstract}

A XVII. századi „akkreditor” (accréditer) szóból származó „akkreditáció” fogalom a „mettre à crédit” ( „hitelt ad”, „hitelesít”) francia kifejezésből ered [1]. Rövid általános magyarázata „hitelt vagy elismerést megadó cselekedet" [2], az aktuális szaknyelvben azonban ennél pontosabban meghatározott: „Egy személy vagy szervezet adott státuszának vagy adott tevékenység végzésére vonatkozó alkalmasság hivatalos elismerése vagy elismerési folyamata” [3].

Az egészségügyi akkreditáció olyan formális eljárás, amely során egy elismert testület, általában nem kor- 
mányzati szervezet (non-governmental organization) felméri és elismeri egy egészségügyi szolgáltató előre meghatározott és közzétett standardoknak való megfelelését $[4,5]$. Az egészségügyi akkreditáció célja Rooney 1999-es munkája [4] alapján:

- az ellátás minőségének javítása egészségügyi szervezetek által elérendő standardokban megadott optimális teljesítménycélok meghatározásával;

- az egészségügyi szolgáltatások integrációjának és szervezettségének serkentése és javítása;

- összehasonlító adatbázis létrehozása adott struktúra, folyamat és eredmény standardoknak vagy kritériumoknak megfelelő egészségügyi szervezetekről;

- az egészségügyi szolgáltatások eredményességének és hatékonyságának növelése által az egészségügyi kiadások csökkentése;

- oktatás és konzultációs lehetőség biztosítása minőségfejlesztési stratégiákról és legjobb gyakorlatokról egészségügyi szervezetek, vezetők és szakemberek számára;

- a lakosság egészségügyi ellátás minőségébe vetett bizalmának erősítése;

- betegek és dolgozók kórházi sérülésekkel és fertőzésekkel összefüggő kockázatának csökkentése.

Magyarországon az egészségügyi ellátók akkreditációjának lehetőségét az egészségügyi törvény 2012-es módosítása tette lehetôvé. Még ugyanezen év decemberében, a TÁMOP-6.2.5.A-13-2012-0001 jelü, Európai Unió által támogatott projekt keretében indult meg az egészségügyi ellátók akkreditációs rendszerének fejlesztése, amely egy múködési standardokon alapuló, egységes külső felülvizsgálati rendszer létrehozását tűzte ki céljául. A kétéves megvalósítási időszak egy problémaalapú fejlesztési módszertan mentén kialakított standardrendszer létrehozását és szűk körû tesztelését foglalta magába. A projekt lezárásával párhuzamosan indult el a TÁMOP-6.2.5-B-13/1-2014-0001 jelü következó komponens, amely az időközben BELLA (BetegELLátók Akkreditációja a biztonságos betegellátásért) névre keresztelt program széles körü bevezetését indította meg tizenkét járó- és harminchárom fekvőbeteg-ellátó intézményben. A magyar akkreditációs rendszer 2016 tavaszára tervezett, éles indulásának küszöbén aktuális és fontos feladat az egészségügyi akkreditáció múltjának és jellemzőinek átfogó ismertetése.

\section{Az egészségügyi akkreditáció rövid története}

Az egészségügyi akkreditáció gyökerei az alig több mint száz évvel ezelőtti Amerikai Egyesült Államok egészségügyi rendszeréhez vezethetőek vissza. A XIX. századi amerikai egészségügyet a szervezetlenség és alacsony ellátási minőség jellemezte, amely felett legnagyobb befolyással az egészségügyi képzést kézben tartó for-profit intézmények bírtak [6]. Ezen állapotok hatására 1910ben fogalmazta meg Ernest A. Codman, a Boston's Mas- sachusetts General Hospital sebésze az igényt a kórházi körülmények javítására és a betegútkövetés bevezetésére, amellyel ellenőrizni lehet az egyes betegek kezelésének eredményességét. Bár eleinte kevesen követték, Codman erőfeszítései hozzájárultak az Amerikai Sebésztársaság (American College of Surgeons - ACS) megalakulásához, amely később elindította Kórházi Standardizációs Programját (Hospital Standardization Program) 1917ben [7]. A „minimumstandardoknak" nevezett, eredeti formájában összesen egyoldalas ajánlás létrejöttét követően az ACS tagjai elkezdték felmérni az egészségügyi szervezetek fogadókészségét az akkreditációra vonatkozóan, és egy éven belül elindultak az első helyszíni felülvizsgálatok [8]. További standardok hozzáadásával végül 1926-ban nyomtatásba került az első, 18 oldalas standardkézikönyv. A kezdeményezés sikerét mutatja, hogy 1952-ben, több egyesült államokbeli és egy kanadai egészségügyi szervezet csatlakozásával megalakult az első egészségügyi akkreditációs szervezet, a Joint Commission on Accreditation of Hospitals (JCAH) $[6,8]$. A JCAH egészen 1966-ig a minimumstandardok alapján végezte tevékenységét, amikorra azonban egyértelmúvé vált, hogy ez a gondolkodásmód nem tartható. Egyrészt, ekkorra a legtöbb amerikai kórház már teljesítette az alapvetô elvárásokat; emellett a múködésbe lépett Medicare rendszer sokkal szigorúbb elvárásokat vezetett be, amelyekre reagálnia kellett a szervezetnek. Avedis Donabedian ez évben megjelent, alapvető jelentőségü cikke az egészségügyi minőségértékelésről [9] világossá tette, hogy az ellátás minőségének értékeléséhez és fejlesztéséhez alkalmazott eszközök sokkal szofisztikáltabbá váltak, ezáltal magasabb elvárásokat támasztottak az akkreditáció elé is. Ettől kezdve a szervezet a minimumelvárásokról az úgynevezett optimálisan elérhető standardok felé mozdult el, szervesen magába foglalva a donabediani struktúra-folyamat-eredmény modellt.

A következő években a rendszer folyamatos fejlődésen ment keresztül: a minőségügy szereplői az eleinte inkább szubjektív betegadat-elemzés felől a standardizált, kimenetelorientált felülvizsgálatok felé mozdultak el; az akkreditációs minősítés időtartamát 2-3 évben maximálták; illetve különböző indikátorok alkalmazását vezették be. Komoly mérföldkőnek számított a JCAH 1988-ban kiadott Agenda for Change dokumentuma, amelyben az iparból átvett folyamatos minóségfejlesztés (continuous quality improvement) elve alapján multidiszciplináris csoportok fejlesztésére fókuszál az egyéni hibák és roszszul teljesítő emberek helyett [10], elítélve ezzel az egészségügyben jellemző egyéni bünbakkeresés jelenségét.

Az amerikai modell ezt követően, az 1990-es években terjedt át előbb az angolszász országokba, majd Európa egyéb országaiba, Latin-Amerikába, Afrikába és NyugatÓceániába [11]. Az akkreditáció elterjedéséhez nagymértékben hozzájárult a Joint Commission által 1994ben alapított Joint Commission International, amely az Egyesült Államokon kívüli intézmények akkreditációját 
kezdte meg, mára pedig több mint 90 országban van jelen 700 feletti akkreditált intézménnyel. Eközben az eredetileg 1984-ben alakult International Society for Quality in Health Care (ISQua) nevú nemzetközi szervezet 1999-ben indította el ALPHA programját (Agenda for Leadership in Programs for Healthcare Accreditation), amelyben alapvető elveket fogalmazott meg az akkreditációs standardok értékeléséhez és az „akkreditálók akkreditációjához” [12]. Ezzel megindult egy akkreditációs programok felett álló, azokat értékelő-minősítő folyamat, amely egységes és megbízható fejlesztési alapot ad a rendkívül sokszínű és sokszor nehezen átlátható módszerekkel kialakított rendszereknek.

Az akkreditáció jelenével kapcsolatban a WHO 2003 as jelentésében [11] az alábbiakat foglalja össze, amely megállapítások jelenleg is helytállóak:

- az elmúlt két évtized adatai alapján becsülve 5 évente megduplázódik az akkreditációs programok száma a világon;

- minden három akkreditációs programból egy kormányzat által jóváhagyott és felhatalmazott módon múködik;

- a legtöbb új program két év alatt jut el a fejlesztés megkezdésétől az első felülvizsgálatig;

- megfigyelhető, hogy az akkreditáció fókusza az egyes egészségügyi egységek (kórház, telephely, részlegek, osztályok stb.) felülvizsgálatáról a betegút követése felé mozdul el;

- az akkreditációs rendszereket egyre inkább jellemzi a transzparencia, ennek jegyében egyre több országban publikálják nyilvánosan a standardokat, és van példa az intézményekről készült akkreditációs jelentés nyilvánosságra hozatalára is.

Az egészségügyi akkreditáció a fejlett országokban mára általánosan elfogadott és elismert eszközzé vált az ellátás minőségének fejlesztéséhez. Az ISQua jelenleg 30 akkreditációs szervezetet és 57 standardrendszert minősített saját standardjai alapján [13]. A kezdetben alapvető múködésre fókuszáló, egy oldalon összefoglalható kezdeményezés mára komplex, rendszerint szigorúan magas, de teljesíthető színvonalat elváró, következetesen tervezett és szervezett, szakmaspecifikus eszközkészletté vált, amelynek fó fókuszába egyre inkább a betegbiztonság kerül. Ez utóbbi szemléletváltást jól mutatja az a tény, hogy miközben a legrégebbi szervezet, a Joint Commission által kiadott alapvetések közé is csak a közelmúltban, 1999-ben került be a betegbiztonság fogalma, 2014-ben már önálló fejezet foglalkozik a betegbiztonsággal a standardkézikönyvben [8].

\section{Az egészségügyi akkreditáció jellemzői és jelentősége}

Az egyes országok többnyire nemzeti fejlesztésű, így a helyi egészségügyi viszonyokat figyelembe vevő akkreditációs rendszerei nagy változatosságot mutatnak mind felépítésük, mind a szabályozott témakörök tekinteté- ben. Az akkreditációs rendszerek diverzifitása visszavezethető az országok eltérő erőforrásból gazdálkodó, eltérő szükségletekre tervezett egészségügyi rendszereinek különbözőségére $[11,14]$. Bár az akkreditáció eredményességének kutatása jelenleg is több kutatócsoport érdeklődésének középpontjában áll, feltételezhetően a helyi sajátosságokhoz igazítottsága teszi képessé arra, hogy bizonyítottan szignifikáns mértékben javítsa az ellátás minőségét és a betegbiztonságot [15].

$\mathrm{Az}$ egészségügyi akkreditáció szereplői két alapvető csoportra oszthatóak: a minősítés alatt álló vagy már minősített egészségügyi ellátó szervezetekre (vagy azok egy meghatározott részére), és a minősítést végző intézményre. Bár az akkreditáció eredetileg a kórházi ellátás minősítésére jött létre, a minősíthető intézmények csoportja mára az ellátói szintek és típusok széles körét öleli fel. Charles Shaw munkája [16] alapján egyes államok között is nagy különbségek mutatkoznak a fókuszt illetően, a teljes egészségügyi szektor számára nyitott akkreditációtól (például Franciaország, Olaszország, Egyesült Királyság [Health Quality System rendszer]) a szúkebb, alap- és kórházi ellátást magába foglaló rendszereken (például Dánia, Spanyolország, Egyesült Királyság [Healthcare Accreditation Programme rendszer]) keresztül a csak legmagasabb szintú, oktatási feladatot is végző kórházakat beengedő rendszerekig (például Németország, Írország). Ritka példaként Finnországban a szociális ellátórendszert is bevonták a programba. Napjainkban az akkreditáció fókuszáról elmondható, hogy ideális esetben olyan teljes ellátórendszereket vizsgál, amelyek képesek önmaguk autonóm szabályozására, és a feltárt hiányosságok kiküszöbölésére. Ezért a legkisebb akkreditálható egység a legtöbb rendszerben egy intézmény vagy annak egy önálló vezetéssel (saját költségvetéssel és belsô szabályzatalkotási jogosultsággal) bíró telephelye. Ennek jelentősége abban áll, hogy az adott egység (telephely, intézmény vagy ennél nagyobb szervezet) önállóan képes saját tevékenységét fejleszteni, valamint abszolút felelősséggel rendelkezik az ellátás minőségére nézve. Az ennél kisebb szervezeti struktúrák ezzel szemben nem képesek kihasználni a különböző, intézményen belüli rendszerek integrált fejlesztéséből adódó előnyöket [16], pedig ez (tudnillik az ellátás és a különböző támogató folyamatok, például humánerőforrás-menedzsment, beszerzés, infekciókontroll stb. közötti együttmúködés szorosabbra füzése) alapvető része az akkreditáció eszközkészletének.

Az akkreditációs folyamat másik szereplője az akkreditációt végző szervezet, amely lehet abszolút állami kézben (például az egészségügyért felelős minisztérium vagy államtitkárság irányítása alatt), vagy ezzel ellentétesen a kormányzattól teljesen független testület, illetve valamely vegyes struktúra alkalmazása. Shaw munkája, valamint az ISQua akkreditációs rendszerekre vonatkozó standardjai [17] alapján egy akkreditációs intézmény alapvető feladatai a következők: 
- a felülvizsgálat alapját képező standardok fejlesztése és kezelése;

- felülvizsgálók kiválasztása, képzése és koordinálása;

- az akkreditációs eljárás, ezen belül különösen a felülvizsgálatok szervezése és lebonyolítása.

Az egészségügyi akkreditáció szakmai alapját az egészségügyre specifikusan fejlesztett standardok adják. A standard olyan, kompetens testület által elöre meghatározott, jól körülhatárolt elvárás, amely leírja egy szervezet elfogadható múködési szintjét [4]. Az ISQua standardokkal szemben megfogalmazott kritériumai alapján az egészségügyi standard a szakmai ellátásnak helyt adó környezettel szembeni elvárásokat tartalmaz, vagyis az egészségügyi szervezetek múködésére fókuszál [18]. Ez rendkívül fontos különbség azon eszközökkel szemben, amelyek az ellátás szakmai minőségét vizsgálják (például klinikai audit), ugyanis az akkreditáció ezáltal a gyógyításhoz kapcsolódó szakmai döntéseket teljes egészében az ellátók kezében hagyja. A standardokat rendszerint szakértők fejlesztik nemzeti szabályozás, kormányzati útmutatók, független jelentések, más standardrendszerek és biomedicinális-egészségügyi kutatások felhasználásával, konszenzusos alapon - ebből adódóan adott rendszertől függően eltérő tartalommal és szerkezetben jelenhetnek meg $[11,19]$. Tartalmukat tekintve a standardok a legtöbb rendszerben az ellátási tevékenységhez kapcsolódó minden intézményi múködési területet lefednek, ideértve az intézményi menedzsmentet és külsőbelső kommunikációs folyamatokat, a közvetlen betegellátáshoz kapcsolódó folyamatokat, az azokhoz szükséges infrastruktúra tervezését és biztosítását, valamint ISQuaelvárásként kötelezően érintik az intézményi stratégiai tervezés, minőségfejlesztés, biztonság/betegbiztonság és infekciókontroll témaköröket [18]. Megfigyelhető, hogy az új, induló standardrendszerek kezdetben alacsonyabb, minimális elvárásokat fogalmaznak meg, majd az akkreditációs kultúra és rendszer fejlődésével fokozatosan az optimumstandardok bevezetése felé mozdulnak el [5]. Ezt a standardok rendszeres, periodikus áttekintésével és frissítésével valósítják meg. Fontos tulajdonsága és egyben erőssége az akkreditációnak, hogy magas szintű, mégis az adott egészségügyi rendszer által elérhető minőségcélok kitűzésére törekszik, ezáltal motiválva a részt vevő intézményeket a folyamatos minőségfejlesztésre [4].

A standardoknak való megfelelés külső felülvizsgálók általi felmérése nem folyamatos (nem monitorozás jellegü tevékenység zajlik), hanem periodikusan, általában 2-3 évente végzett helyszíni felülvizsgálat (on-site survey, site visit) segítségével történik. Ezt számos rendszerben egy, a felülvizsgálandó intézmény által átlagosan fél évvel korábban végzett önértékelési folyamat előzi meg. Az önértékelés jelentőségét az érintett intézmény önálló tanulási folyamata és a kritikus-értékelő szemléletmód elsajátítása adja; a saját múködési folyamatok szisztematikus áttekintése érdemben befolyásolja és fejleszti az ellátók és a vezetők minőségfejlesztéssel szembeni attitűd- jét. Az elkészült önértékelési jelentés emellett fontos támpontot ad a felülvizsgálatot végzők számára. A felülvizsgálat lényegében egy rendkívül intenzív, szoros programterv alapján végrehajtott helyszínbejárás és interjúsorozat, amely során a standardok által szabályozott struktúrákat, folyamatokat és adott esetben az eredményeket valós időben, múködés közben tekintik meg, és értékelik. Ez azt jelenti, hogy az akkreditáló szervezetet képviselő felülvizsgálók (akik szigorúan nem állhatnak kollegiális vagy egyéb közeli kapcsolatban a felülvizsgált intézménnyel) személyesen látogatnak el a minősítés alatt álló intézménybe, ahol az alábbi felülvizsgálati technikákkal mérik fel a standardok teljesülését [4]:

- személyes interjúk (vezetókkel, klinikai ellátókkal és kisegítő személyzettel, illetve betegekkel és hozzátartozóikkal);

- a betegellátás és az ahhoz kapcsolódó szolgáltatások megfigyelése;

- az intézményi épületek, a fizikai környezet megfigyelése;

- belső szabályozók, eljárások, oktatási programok és egyéb anyagok áttekintése;

- meghatározott eredménymutatók, indikátorok értékelése;

- betegdokumentáció áttekintése.

Az akkreditáció egyik fó erôssége, hogy tudatosan a tényleges múködésre, nem pedig a dokumentáció és szabályozások ellenőrzésére fókuszál - az utóbbi önmagában ugyanis könnyen adhat megtévesztően pozitív képet egy intézményről. A WHO 2003-as felmérése [11] alapján a felülvizsgálat időtartama és a felülvizsgálói team létszáma az intézmény méretétől függően változik; az átlagos időtartam 3 nap (a szórás 0,5-8 nap), az átlagos létszám 3 fó (a szórás 2-12 fó). A standardok rendszerint az intézményi múködés jelentős részét lefedik (minden, ellátáshoz kapcsolódó struktúrát és folyamatot, ideértve a fizikai környezetet és eszközparkot, takarítást és sterilizálást, hulladékkezelést, étkeztetést, beszerzést, diagnosztikus és analitikus szolgáltatásokat, gyógyszertári tevékenységet és raktározást, halottkezelést stb.), ezért a minősülő intézmény átvizsgálása hatalmas és időigényes feladat, akár napi 10-12 óra aktív munkát is igényelhet a felülvizsgálatot végző csapattól, illetve aktív támogatást és szervezési segítséget a fogadó intézménytől. Bár felmérések szerint mind a felülvizsgáló, mind a felülvizsgált oldal az idő szúkösségét jelezte leggyakrabban, sem a felülvizsgálói létszám, sem az idő növelése nem feltétlenül jó megoldás ezen problémára a költségek és a folyamat komplexitásának, valamint a fogadó intézmény számára jelentkező terhek túlzott növekedése miatt [16].

A helyszíni felülvizsgálatot egészségügyi végzettségű szakemberekből álló multidiszciplináris team végzi. Szakmai megfelelőséget legmagasabb színvonalon csak az értékelt szakmában járatos, gyakorló szakember vizsgálhat, ezért az akkreditációs rendszerek egyik fó jellemzője és erőssége a kollegiális ellenőrzés, angol szakkifejezéssel peer review alkalmazása. A kollegiális ellenőrzés 
adott szakemberek tevékenységének azonos tudományos vagy szakmai területen dolgozó, az elismerés alatt álló intézménytől független személyek („peerek”) általi értékelését jelenti [20]. A lehető legmagasabb szakmai színvonalú peerértékelés megvalósulása érdekében a legtöbb rendszerben elvárás, hogy a felülvizsgálók egészségügyi gyakorlati tapasztalattal rendelkező ellátók legyenek. Fejlettebb rendszerekben az elözőek mellett törekednek arra, hogy a felülvizsgálókat már akkreditált intézményekból toborozzák, a felülvizsgálati feladatok mellett aktív ellátói tevékenységet végezzenek, és az általános gyakorlati tapasztalaton felül oktatási, minőségügyi és/ vagy menedzsmentismeretekkel rendelkezzenek [21]. Ezen magas elvárásokat indokolja, hogy a felülvizsgálók nem pusztán passzív, értékelő funkciót töltenek be, hanem kiemelkedő szerepük van az intézmények felkészítésében és oktatásában akár szervezett, felülvizsgálatot megelőző tanácsadás formájában, akár az akkreditációs eljárás folyamán. Éppen ezért a felülvizsgálók alapos képzésen vesznek részt aktív tevékenységük megkezdése előtt, azt követően pedig folyamatos értékelés és továbbképzés alatt állnak. A felülvizsgálói képzés fontosságát jelzi, hogy az ISQua külön akkreditálja a képzési programokat [22], amelyek számára alapvető elvárás a standardok értelmezésének oktatása, a felülvizsgálati eljárás alapvető tevékenységét képező interjúkészítési, megfigyelési és dokumentációelemzési technikák átadása, speciális területekre (betegbiztonság, infekciókontroll stb.) érvényes tudnivalók ismertetése és a jelentésírás módszertanának oktatása [16].

Az akkreditáció a mai napig túlnyomórészben az állami szférától függetlenül vagy azzal együttmúködve, önkéntes formában létezik. Eszerint az intézmények maguk dönthetnek arról, hogy belépnek a rendszerbe és akkreditációs minősítésért folyamodnak vagy sem. A belépésre számos motivációs erő létezik, úgymint:

- jelentős szervezetfejlesztési lehetőség (önértékelés, csapatépítés és összehasonlítási alap, úgynevezett „benchmark” lehetőségek által);

- potenciális többletforrás vagy megtakarítás (adott országok állami biztosítói kedvezményekben, előnyösebb díjszabásban részesítik az akkreditált intézményeket);

- magánbiztosítók bevonzása (azokban az országokban, amelyekben magánbiztosítói rendszer múködik, jellemzően szívesebben kötnek szerződést a magánszektor képviselői akkreditált intézményekkel);

- piacszerzési lehetőség (az akkreditációval járó elismertség több beteget és szakembert vonz az intézményhez);

- csökkenő felelősségbiztosítási költségek (a minősítés alacsonyabb kockázati kategóriába sorolást eredményezhet);

- hatósági ellenőrzések könnyítése (egyes államokban a felügyeleti szervek enyhébb ellenőrzésben részesítik az akkreditációval rendelkező intézményeket);

- adott esetben kedvezőbb állami pályázati feltételek;
- csökkenő múhibaperköltségek a megbízható és egységes folyamatokból adódóan; valamint

- előny nemzeti minőségi díjak elbírálásakor [16].

Az ösztönzők mellett meg kell említeni visszatartó tényező́ként a növekvő költségeket. (Költségnek tekinthető az akkreditációs standardok gyakorlatba ültetésére fordított idő, menedzsment-erőforrás és pénz.) Bizonyos szempontból nem meglepő módon az eredményektől való félelem is komoly problémát és konfliktusokat okozhat: a feltárt hiányosságok esetleges szankcionálása bűnbakkeresésból adódóan; a sikertelen akkreditáció esetén a dolgozói morál csökkenése; a teljesítményadatok téves használata; illetve az akkreditáció megszerzése, majd késóbbi elvesztése a standardok egyre növekvő elvárásai miatt [16].

Az egészségügyi akkreditáció specifikumainak bemutatása végén indokolt szót ejteni ezen rendkívül komplex és nagyszabású rendszer jelentőségéről, amely kifejlesztésébe és múködtetésébe az elmúlt évtizedekben hatalmas és egyre növekvő összegeket fektetnek. Bár egy WHO-találkozón már 1995-ben kimondták, hogy az akkreditáció a legfontosabb módszer az egészségügyi minőségfejlesztési technikák közül [23], tényleges eredményességéról beszámoló kutatások csak több mint egy évtizeddel később kezdtek megjelenni a szakirodalomban. Greenfield és munkatársai 2008-ban még csak két területen, a pozitív szervezeti változás és a szakmai fejlődés előidézésében találtak szignifikáns hatást [24]. Három évvel később Alkhenizan és Shaw már egyértelműen arról számolnak be, hogy az akkreditáció javítja az ellátás folyamatát és növeli a klinikai eredményességet az ellátás széles spektrumán [25]. 2012-ben Hinchcliff irodalmi áttekintés alapján megerósíti ezt, kimondva az egészségügyi akkreditáció hasznosságát az egészségügyi szolgáltatások magas szintú ellátásának és magas minőségú szervezeti folyamatainak kialakításában [26]. Ezzel öszszecseng több, szolgáltatók és akkreditációban részt vevők körében készített korábbi felmérés, amelyek közösen említik az alábbi előnyöket [16]:

- szorosabb és jobb csapatmunka és belső szervezeti kohézió (szorosabb kooperáció szakmacsoportok, részlegek/intézetek, klinikusok és kisegítő szolgáltatások, valamint vezetők és klinikusok között);

- szabályok felülvizsgálata (a klinikai és adminisztratív folyamatok érdemi fejlesztése és egységesítése belső konzultációk mentén);

- minőségcélok összehangolása (különböző ellátói csoportok minőségügyi tevékenységének és tudásának összekapcsolása);

- standardok alkalmazása (a nem együttmúködő területek azonosítása és kiküszöbölése önértékelési technikákkal);

- külső kapcsolatépítés (tapasztalt ellátókkal való kapcsolatfelvétel más egészségügyi intézményekből az akkreditációnak köszönhetően); 
- külső publicitás és marketingelőnyök (az intézményről alkotott nyilvános vélemény javítása, valamint munkaerő és igénybevevők bevonzása).

\section{Az egészségüigyi akkreditáció és a tanúsítás viszonya}

Jelenleg aktív fejlesztés alatt áll az első magyar akkreditációs rendszer - emellett ugyanakkor nem hagyható figyelmen kívül, hogy a magyar egészségügyi minőségirányítás kultúrájában már két évtizede aktívan jelen van a Nemzetközi Szabványügyi Szervezet (International Organization for Standardization) nevéhez kapcsolódó tanúsítási rendszer, az ISO. (A Zala Megyei Kórház már 1995-ben tanúsítást szerzett, az országban elsőként [27].) Az akkreditáció megjelenése ezért számos egészségügyi intézménynél okozott fogalmi és tartalmi zavart is; szakmai találkozókon rendszeresen keverednek a „tanúsítás”, „akkreditáció”, „felülvizsgálat/felülvizsgáló”, „audit/auditor" és további, adott rendszerekhez kapcsolódó szakkifejezések. Mivel a két rendszer tartalmában, ezáltal intézményre gyakorolt hatásaiban is eltér egymástól, a fogalmak következetes használata kívánatos. Bár szakmai körökben elkülönítik a minóségbiztositás (úgymint a szabályok szerinti múködés kialakítása és fenntartása) és a minóségfejlesztés (úgymint a folyamatok folyamatos elemzése és fejlesztése) fogalmát [28] - az ISO-rendszert inkább az előbbi, az akkreditációt pedig az utóbbi kategóriába sorolva -, az egyes országokat összehasonlítva alapvetően kevés következetesség fedezhető fel abban a tekintetben, hogy mely intézmények melyik rendszert alkalmazzák a gyakorlatban [29]. A fogalmak közötti eligazodásban az 1. táblázat ad támpontot.

Az ISO 9001-es szabványt (a magyar szaknyelvben az elvárások szerkesztett formája tanúsítás esetén „szabvány”, akkreditáció esetén standard néven kerül megkülönböztetésre) először 1996-ban vezette be egy egyesült

1. táblázat Az akkreditációval és ISO-tanúsítással kapcsolatos szakkifejezések és jellemzók bemutatása, Rooney és Shaw nyomán (saját szer kesztés) $[4,16]$

\begin{tabular}{|c|c|c|c|c|}
\hline $\begin{array}{l}\text { Minősítő } \\
\text { folyamat }\end{array}$ & $\begin{array}{l}\text { Kritérium- } \\
\text { egység }\end{array}$ & $\begin{array}{l}\text { Helyszíni } \\
\text { ellenőrzés }\end{array}$ & $\begin{array}{l}\text { Ellenőrzést } \\
\text { végző } \\
\text { személy }\end{array}$ & $\begin{array}{l}\text { Múkködtető } \\
\text { jellege }\end{array}$ \\
\hline $\begin{array}{l}\text { Akkre- } \\
\text { ditáció }\end{array}$ & $\begin{array}{l}\text { Standard } \\
\text { (nyilvános) }\end{array}$ & $\begin{array}{l}\text { Helyszíni } \\
\text { felül- } \\
\text { vizsgálat }\end{array}$ & $\begin{array}{l}\text { Felül- } \\
\text { vizsgáló } \\
\text { (kollegiális } \\
\text { ellenőrzés } \\
\text { kötelező) }\end{array}$ & $\begin{array}{l}\text { Állami vagy } \\
\text { független, } \\
\text { nem } \\
\text { kormányzati } \\
\text { szervezet }\end{array}$ \\
\hline Tanúsítás & $\begin{array}{l}\text { Szabvány } \\
\text { (korláto- } \\
\text { zottan } \\
\text { hozzá- } \\
\text { férhetó) }\end{array}$ & $\begin{array}{l}\text { (külső) } \\
\text { Audit }\end{array}$ & $\begin{array}{l}\text { Auditor } \\
\text { (kollegiális } \\
\text { ellenőrzés } \\
\text { nem } \\
\text { kötelező) }\end{array}$ & $\begin{array}{l}\text { Engedélye- } \\
\text { zett } \\
\text { kormányzati, } \\
\text { vagy profit- } \\
\text { orientált } \\
\text { piaci } \\
\text { szervezet }\end{array}$ \\
\hline
\end{tabular}

államokbeli kórház (American Legion Hospital, Crowley, LA), mint minőségmenedzsment-rendszert (quality management system) [30]. Az ipar számára fejlesztett minőségirányítási szabványok ilyen módon a kórházi múködésre is értelmezésre kerültek, bár a szövegezésen erősen érződik a gazdasági szemlélet: számos helyen szerepelnek az elvárások szövegében a „termék”, „vevő”, „szerződés” szavak, amelyek bár ez esetben egészségügyre definiáltak, a szakmabeliek számára idegen kifejezések. Ettől függetlenül a rendszer alkalmazható az egészségügyben, és képes a múködés széles körü lefedésére: a 9001-es szabvány négyes záradéka írja le a minőségügyi rendszerrel kapcsolatos elvárásokat, amely 20 múködési területet határoz meg és értelmez az ellátói vagy ellátással kapcsolatban álló tevékenységekre és müködésre [30]. Ezek között szerepel: vezetői felelősség, minőségügyi rendszer, dokumentáció- és adatkezelés, folyamatkontroll, ellenőrzés és tesztelés, nem megfelelő termékek (például eszközök és ellátási folyamatok) kezelése, raktározás-szállítás, minőségügyi adatok kezelése, belső minőségi auditok, képzés stb. A címszavak általánossága jól mutatja a rendszer alacsony egészségügyi specifikusságát, ugyanakkor bizonyítja a korábban említett átfogó rendszerszemléletet. Éppen ezért a tanúsítás alkalmazása is képes eredményesen fejleszteni egy olyan intézmény múködését, ahol nem alkalmaztak még semmilyen minőségügyi rendszert - ezt tudományos kutatás keretében is megerősítették [29].

Az ISO-tanúsítás és az akkreditáció közötti elsődleges különbség tehát az egészségügyre specifikusság mértéke. Az ISO-szabványokat eredetileg az ipari múködésre fejlesztették ki, ezáltal általános minőségmenedzsment-elvárásokat tartalmaznak - ez ugyanakkor jelentősen nagyobb összehasonlíthatóságot eredményez nemzetközi szinten, amely több intézmény számára ösztönző lehet a tanúsítás megszerzésére. A minőségügyi eszközök eredményességét Shaw kutatta több tanulmányban. Az akkreditáció és az ISO-tanúsítás összehasonlításáról írt 2010-es, 71 kórház bevonásával készült cikkében hat vizsgált területből háromban (kórházi menedzsment, betegbiztonság, klinikai gyakorlat) teljesített jobban az akkreditáció, míg háromban (betegjogok, klinikai tevékenység szervezése, környezet) nem volt különbség a két rendszer között [29]; ugyanakkor minden olyan intézmény, amely vagy akkreditációval, vagy tanúsítással rendelkezett, jobban teljesített a minőségügyi rendszert nem múködtető intézményekkel szemben. A DUQuE projekt adatai alapján készült 2014-es cikkben az akkreditáció a klinikai vezetés és az ellenőrzés területeken mutatott jobb teljesítményt a tanúsításnál, bár ez nem minden esetben volt szignifikáns [31]. A tanulmány fó konklúzióként emellett a mindkét típusú minősítéssel rendelkező intézmények szignifikánsan jobb teljesítményét is hangsúlyozza. A két publikáció ugyanakkor megállapítja, hogy eredményeiket érdemes fenntartással kezelni, tekintve az alacsony statisztikai elemszámot, illetve egyéb esetleges torzító hatásokat (például annak a lehe- 
tősége, hogy túlnyomórészt jól teljesítő és ambiciózus kórházak jelentkeztek a felmérésbe, ezért a minta alapból torz).

További különbségek mutatkoznak az akkreditáció és a tanúsítás között a rendszerek szervezését tekintve. Az akkreditációs rendszerekkel szemben alapvető ISQua-elvárás a standardok, a felülvizsgálati módszertan és az értékelési szempontok nyilvános közzététele, elérhetőségük biztosítása [18], míg az ISO-auditok esetében az auditeljárás és a döntési kritériumok nem publikáltak. Ennek hátterében fontos tényező az auditcégek között fennálló természetes piaci versenyhelyzet, szemben az akkreditációs rendszerek rendszerint országos szintü, nonprofit múködésével. Mindez csökkenti az ISO-audit értékelési folyamatának átláthatóságát. Az akkreditáció esetében alapelv a felülvizsgálók peer státuszának kizárólagossága, míg az auditorokkal szemben ez nem kizáró jellegű elvárás; emellett pedig az akkreditációs felülvizsgálók képzési és teljesítményértékelési módszertana is hozzáférhető, szemben az auditszervezetek gyakorlatával.

Új színt hozott a minőségügyi területbe az ISO által kiadott és hazánkban 2014-ben közzétett MSZ EN 15224:2013 jelú szabvány, amely kifejezetten az egészségügyi ellátásra készült. Az új „egészségügyi ISO-szabványt” Guba és Seres cikksorozatban mutatták be és hasonlították össze az eredeti 9001-es szabvánnyal [32, 33]. Megállapításaik szerint az új szabvány alapjaiban jelentősen hasonlít a 9001-esre, annak minőségirányítási alapelveit azonban tizenegy, egészségügyre vonatkozó minőségjellemzővel egészíti ki:

- helyes, szakszerű ellátás;

- rendelkezésre állás;

- az ellátás folytonossága;

- eredményesség;

- hatékonyság;

- méltányosság;

- bizonyítékokon/ismereteken alapuló szolgáltatás;

- betegközpontú ellátás, beleértve a fizikai, pszichológiai és társadalmi sérthetetlenséget;

- a beteg bevonása;

- a beteg biztonsága;

- időszerúség/hozzáférés.

Ezen jellemzők valóban lefedik az egészségügyi ellátás lényeges pontjait, azonban általános jellegükből adódóan nehezen megfoghatóak, illetve tényleges megvalósításuk irreálisan magas feladatmennyiséget róna a szolgáltatókra. Az új szabvány másik jelentős újítása a klinikai folyamatok, az egészségügyi kockázatkezelés és az indikátorok használatának bevonása az ISO-rendszerbe [33]. Számos kifejezés és szóhasználat közelebb került az egészségügyi ellátáshoz (termék helyett inkább „szolgáltatás” fogalom használata, vevők helyett „betegek és egyéb vevők" meghatározás, illetve többek közt a vevői elégedettség, folyamat, követelmény, kockázatelemzés, kockázatkezelés fogalmak pontos meghatározása).

Az új szabvánnyal kapcsolatban értelemszerüen még nincsenek dokumentált, gyújtött és elemzett adatok, visszajelzések. Bár az ISO jelentôs lépést tett az egészségügy felé az MSZ 15224-es szabvány megalkotásával, az első benyomások alapján az akkreditáció továbbra is specifikusabb eszköz marad: míg az előbbi rendkívül széles ellátói kört nevesít tanúsítható intézményként ugyanazon standardkészlet felhasználása alapján (alapellátás, kórházi ellátás, ápolási otthonok, hospice, mentális ellátóhelyek, fogorvosi rendelők, fizikoterápia, foglalkozásegészségügy, rehabilitáció és gyógyszertárak [32]), addig az akkreditáció jelenleg is számos rendszerben külön standardokkal rendelkezik a különféle ellátási formákra vonatkozóan (például külön járó- és fekvőbeteg-ellátási vagy gyógyszertári standardok), középpontba állítva az egyes szolgáltatótípusoknál jelentkező eltérő kockázatokat.

\section{Következtetések}

Az akkreditáció napjainkban számos fejlett országban sikerrel alkalmazott minőségfejlesztési eszköz. Az egészségügyi technológia fejlesztésével párhuzamosan az ellátási színvonal és eredményesség, a betegbiztonság és a hatékonyság növelése egyre jelentősebb hangsúlyt kap világszerte. Ezen tendencia üzenete világos: a minőségfejlesztésnek a gyógyítás mellett az egészségügyi szakemberek tevékenységének szerves részévé kell válnia. Az akkreditáció erre szolgáltat megoldást olyan módon, hogy szervezett formában segíti az egészségügyi ellátás múködési területeit; szigorú, de elérhetô, az adott ország helyzetéhez igazított elvárásokat fogalmaz meg, miközben a gyógyítás szabadságát, a szakmai döntéseket érintetlenül hagyja az ellátók kezében. A mára tudományosan is bizonyítottan eredményes rendszer azonban csak akkor lehet érdemben és hosszú távon sikeres, ha alkalmazói, az egészségügyi dolgozók elfogadják és segítik a múködését. Ehhez elengedhetetlen a rendszer alapvető céljainak, értékeinek, múködésének és eszközeinek ismerete, amelyet segítendő jött létre jelen összefoglaló.

Anyagi támogatás: A szerzők a közlemény megírásáért és a közlemény alapját képező ismeretek összegyưjjtéséért, összeállításáért anyagi támogatásban nem részesültek.

Szerzői munkamegosztás: F. G.: Irodalomkutatás, információk szintetizálása, szövegezés. B. É., L. J.: Szakmai lektorálás, a kézirat szövegezésének véglegesítése. A cikk végleges változatát mindhárom szerző elolvasta és jóváhagyta.

Érdekeltségek: A szerzők a magyar akkreditációs rendszer fejlesztésének aktív résztvevői. 


\section{Irodalom}

[1] Harper, D.: Dictionary.com: Online Etymology Dictionary 2010. http://dictionary.reference.com/browse/accreditation

[2] Accreditation. American Heritage ${ }^{\circledR}$ Dictionary of the English Language. Fifth Edition, 2011. http://www.thefreedictionary. com/accreditation (accessed: 23.05.2015.)

[3] Oxford Dictionaries. Oxford University Press, Oxford, 2015. http://www.oxforddictionaries.com/definition/american_english/accreditation

[4] Rooney, A. L., Ostenberg, P. R.: Licensure, accreditation, and certification: Approaches to health services quality. Quality Assurance Project, Bethesda, 1999

[5] Shaw, C.: The external assessment of health services. World Hosp. Health Serv., 2004, 40(1), 24-27.

[6] Luce, J. M., Bindman, A. B., Lee, P. R.: A brief history of health care quality assessment and improvement in the United States. West, J. Med., 1994, 160(3), 263-268.

[7] Roberts, J. S., Coale, J. G., Redman, R. R.: A history of the Joint Commission on Accreditation of Hospitals. JAMA, 1987, 258(7), 936-940.

[8] The Joint Commission. Over a century of quality and safety. 2014. http://www.jointcommission.org/assets/1/6/TJC_history_timeline_2014.pdf

[9] Donabedian, A.: Evaluating the quality of medical care. Milbank Mem. Fund Q., 1966, 44(3 Suppl.), 166-206.

[10] Berwick, D. M.: Continuous improvement as an ideal in health care. N. Engl. J. Med., 1989, 320(1), 53-56.

[11] World Health Organization: Quality and accreditation in health care services: a global review. WHO, Geneva, 2003. www.who int/hrh/documents/en/quality_accreditation.pdf

[12] Heidemann, E. G.: The ALPHA program. Agenda for Leadership in Programs for Healthcare Accreditation. Int. J. Qual. Health Care, 1999, 11(4), 275-277.

[13] ISQua Accredited Organisations and Standards. International Society for Quality in Health Care. http://www.isqua.org/accreditation/accredited-organisations-standards

[14] Shaw, C. D.: External quality mechanisms for health care: summary of the ExPeRT project on visitatie, accreditation, EFQM and ISO assessment in European Union countries. External Peer Review Techniques. European Foundation for Quality Management. International Organization for Standardization. Int. J. Qual. Health Care, 2000, 12(3), 169-175.

[15] Suñol, R., Vallejo, P., Thompson, A., et al.: Impact of quality strategies on hospital outputs. Qual. Saf. Health Care, 2009, 18(Suppl. 1), i62-i68.

[16] Shaw, C. D.: Toolkit for Accreditation Programs. The International Society for Quality in Health Care, Melbourne, 2004.

[17] ISQua: International Accreditation Standards for Healthcare External Evaluation Organisations. Third Edition. The International Society for Quality in Health Care, Dublin, 2007. http:// www.isqua.org/docs/iap-documents/isqua-s-internationalaccreditation-standards-for-healthcare-external-evaluations-3rdedition.pdf? sfvrsn=0

[18] ISQua: International Principles for Healthcare Standards. Third Edition. The International Society for Quality in Health Care, Dublin, 2007. http://www.isqua.org/docs/default-source/accreditation/international-principles-for-healthcare-standards--b.pdf? sfvrsn=0

[19] Heidemann, E. G.: The contemporary use of standards in health care. World Health Organization, Geneva, 1993.
[20] Peer review. Oxford University Press: Oxford Dictionaries. 2015 http://www.oxforddictionaries.com/definition/english/peerreview

[21] Miller, S.: Participation of surveyors in safety and quality accreditation. Australian Commission on Safety and Quality in Health Care, 2009. http://www.safetyandquality.gov.au/wp-content/ uploads $/ 2012 / 01 /$ Literature-review-on-accreditation-surveyor-management.pdf

[22] ISQua.: Surveyor Training Standards Programme. The International Society for Quality in Health Care, Dublin, 2009. http:// www.isqua.org/docs/iap-documents/isqua-s-surveyor-trainingstandards-programme-2nd-edition.pdf? sfvrsn $=0$

[23] World Health Organization: Applicability of different quality assurance methodologies in developing countries. Proceedings of a pre-ISQua meeting. http://apps.who.int/iris/bitstream/10665/63002/1/WHO_SHS_DHS_96.2.pdf

[24] Greenfield, D., Braithwaite, J.: Health sector accreditation research: a systematic review. Int. J. Qual. Health Care, 2008, 20(3), 172-183.

[25] Alkhenizan, A., Shaw, C.: Impact of accreditation on the quality of healthcare services: a systematic review of the literature. Ann. Saudi Med., 2011, 31(4), 407-416.

[26] Hinchcliff, R., Greenfield, D., Moldovan, M., et al.: Narrative synthesis of health service accreditation literature. BMJ Qual. Saf., 2012, 21(12), 979-991.

[27] Winner of the public provider category of the National Quality Award: Zala County Hospital. [A Nemzeti Minőségi Díj közszolgáltatói kategóriájának első nyertese: a Zala Megyei Kórház.] http://www.zmkorhaz.hu/viewer.php?docid=1210 [Hungarian]

[28] Belicza, É., Zékány, Z.: Connotation system of quality in health care. [A minőség fogalmi rendszere az egészségügyben. Belicza, É. (ed.)] Egészségügyi Minőségfejlesztési Konzultációs Központ, Debrecen, 1998. [Hungarian]

[29] Shaw, C., Groene, O., Mora, N., et al.: Accreditation and ISO certification: do they explain differences in quality management in European hospitals? Int. J. Qual. Health Care, 2010, 22(6), 445-451.

[30] Kolka, J. W.: American Society for Quality. ISO 9001 and Health Care: Easier, faster and better than other accreditation programs. 1999. http://asq.org/quality-progress/1999/08/standardsoutlook/iso-9001-and-healthcare.html

[31] Shaw, C. D., Groene, O., Botje, D., et al.: The effect of certification and accreditation on quality management in 4 clinical services in 73 European hospitals. Int. J. Qual. Health Care, 2014, 26(Suppl. 1), 100-107.

[32] Seres, J., Guba, T.: What about you, MEES? The introduction of "MSZ EN 15224:2013 Health Care Services - Quality Management Systems" standard. [Mi lesz veled MEES? Az MSZ EN 15224:2013 Egészségügyi szolgáltatások. Minőségirányítási rendszerek címú szabvány bemutatása.] IME, 2014, 13(7), 2024. [Hungarian]

[33] Guba, T., Seres, J.: ISO 9001 vs. MSZ 15224 - comparison of a general (process control) and a profession-specific (process control and risk management) standard. [ISO 9001 kontra MSZ 15224 - egy általános (folyamatirányítás) és egy szakmaspecifikus (folyamatirányítási és kockázatkezelési) szabvány összehasonlítása.] IME, 2015, 14(3), 34-39. [Hungarian]

(Fügedi Gergely dr., Budapest, Kútvölgyi út 2., 1125 e-mail: fugedi@emk.sote.hu) 